Brit. J. industr. Med., 1964, 21, 38.

\title{
THE MORTALITY OF MINERS AND EX-MINERS IN THE RHONDDA FACH
}

\author{
BY \\ A. L. COCHRANE, R. G. CARPENTER, F. MOORE, and J. THOMAS
}

(RECEIVED FOR PUBLICATION MAY 2, 1963)

From the Department of Tuberculosis and Chest Diseases, Welsh National School of Medicine, Sully Hospital, near Penarth, the Medical Research Council's Epidemiological Research Unit, Cardiff, the Department of Human Ecology, Cambridge, and the Medical Research Council's Pneumoconiosis Research Unit, Llandough Hospital, near Penarth, Glam.

A six-year follow-up of 6,474 miners and ex-miners, originally radiographed in 1950-51, has been completed. They represent $97 \%$ of all those who were then resident in the Rhondda Fach. In addition, 2,750 non-miners living in the same area were also studied. Death certificates were obtained for all those who had died, including those who had left the area. Standardized mortality ratios (S.M.R.s) have been calculated for the various age and $x$-ray category groups.

The results suggest that (1) progressive massive fibrosis (P.M.F.) is a more serious disease than a previous study suggested; (2) the S.M.R. of miners and ex-miners without P.M.F. is also significantly raised; (3) there is no sign of any relation between the $x$-ray category of simple pneumoconiosis and the S.M.R.; and (4) the S.M.R. of ex-miners is significantly higher than that of miners.

In a previous paper (Carpenter, Cochrane, Clarke, Jonathan and Moore, 1956) an attempt was made to see whether the international radiographic classification of the pneumoconioses could be validated predictively by reference to mortality rates of coalminers. On that occasion the results of a two-and-ahalf-year follow-up were reported; the present paper concerns a six-year follow-up of the original population.

\section{Material}

The material consists of (1) the male population in the Rhondda Fach defined by nominal census during the winter $1950-51$; (2) their ages at that time; (3) the $x$-ray category of coal-workers' pneumoconiosis (International Labour Organisation, 1953) of those miners and ex-miners who were radiographed at that time; (4) information as to who was alive and who was dead on December 1, 1956, including those who had left the area; and (5) copies of the death certificates of all those who had died. The coding of the death certificates was carried out by the Registrar General's Department.

The word 'miner' in this paper refers to a man who was working as a coal-miner at the time of the survey in 1950-51; ' ex-miner' refers to a man who was not working as a coal-miner at that time, but who had previously worked as a coal-miner for at least one year; a 'non-miner' refers to a man not working as a coal-miner at the time of the survey and who had in the past worked less than one year as a miner. The material is summarized in Table 1 .

The material differs from the previous material not only in the longer follow-up, but also in the fact that those who were not radiographed in 1950-51 have been divided into non-miners, on the one hand, and miners and ex-miners on the other. We also made a small retrospective reduction in the numbers of miners and ex-miners who had previously refused to be radiographed. In the previous paper we pointed out the high S.M.R. of those who were not radiographed and discussed how it might have influenced the results. To minimize this possible error we made a search for films taken by other agencies of those who had previously refused to be radiographed by us. We also relaxed our standards about the date on which the radiographs had been taken, accepting some films which had been taken a considerable time after the survey. This was, we thought, justified by the fact that the majority were radiographs of exminers in which progression of simple pneumoconiosis was unlikely to have occurred. In the case of massive fibrosis, the use of these later films may lead to an over-estimate of the category of P.M.F. at the time of the initial survey. However, as the subjects were mostly in the higher age groups, the error should be small because the rate of progression of 
TABLE 1

POPULATION OF NON-MINERS, MINERS, AND EX-MINERS IN 1950-51

\begin{tabular}{|c|c|c|c|c|c|c|c|c|}
\hline \multirow{3}{*}{$\begin{array}{c}\text { Age } \\
\text { Group }\end{array}$} & \multicolumn{4}{|c|}{ Non-miners } & \multicolumn{4}{|c|}{ Miners and Ex-miners } \\
\hline & \multirow{2}{*}{$\begin{array}{l}\text { Total } \\
\text { No. }\end{array}$} & \multirow{2}{*}{ Lapses } & \multicolumn{2}{|c|}{$\begin{array}{c}\text { Total } \\
\text { Radiographed }\end{array}$} & \multirow{2}{*}{$\begin{array}{l}\text { Total } \\
\text { No. }\end{array}$} & \multirow{2}{*}{ Lapses } & \multicolumn{2}{|c|}{$\begin{array}{c}\text { Total } \\
\text { Radiographed }\end{array}$} \\
\hline & & & No. & $\%$ & & & No. & $\%$ \\
\hline $\begin{array}{l}15- \\
20- \\
25- \\
35= \\
45= \\
55= \\
65= \\
75= \\
85+\end{array}$ & $\begin{array}{r}606 \\
493 \\
737 \\
447 \\
223 \\
148 \\
64 \\
27 \\
5\end{array}$ & $\begin{array}{r}19 \\
14 \\
33 \\
29 \\
24 \\
17 \\
12 \\
6 \\
2\end{array}$ & $\begin{array}{r}587 \\
479 \\
704 \\
418 \\
199 \\
131 \\
52 \\
21 \\
3\end{array}$ & $\begin{array}{l}96.9 \\
97 \cdot 2 \\
95.5 \\
93.5 \\
89.2 \\
88.5 \\
81 \cdot 3 \\
77 \cdot 8 \\
60.0\end{array}$ & $\begin{array}{r}289 \\
324 \\
1146 \\
1346 \\
1337 \\
1173 \\
765 \\
275 \\
20\end{array}$ & $\begin{array}{r}-1 \\
8 \\
14 \\
13 \\
32 \\
58 \\
66 \\
9\end{array}$ & $\begin{array}{r}289 \\
323 \\
1138 \\
1332 \\
1324 \\
1141 \\
707 \\
209 \\
11\end{array}$ & $\begin{array}{r}100 \cdot 0 \\
99.7 \\
99.3 \\
99.0 \\
99.0 \\
97 \cdot 3 \\
92.4 \\
76.0 \\
55.0\end{array}$ \\
\hline All ages & 2750 & 156 & 2594 & $94 \cdot 3$ & 6675 & 201 & 6474 & 97.0 \\
\hline $20-64$ & 2048 & 117 & 1931 & $94 \cdot 3$ & 5326 & 68 & 5258 & $98 \cdot 7$ \\
\hline $25-74$ & 1619 & 115 & 1504 & 92.9 & 5767 & 125 & 5642 & $97 \cdot 8$ \\
\hline
\end{tabular}

P.M.F. decreases with increasing age (Cochrane, Carpenter, Clarke, Jonathan and Moore, 1956; Cochrane, Moore and Thomas, 1961a). A few corrections were also made to the ages, after comparing the statement on the death certificate with our previous estimate. Similarly, a few radiographs were reclassified when we found radiographs of better technique, or of a date closer to that of the survey in 1950-51. For example, in the age group 20-64 with radiographs showing category 0 the number of deaths fell from 72 to 63 . This was due to four deaths being transferred to higher age groups and eight being transferred to higher $x$-ray categories. At the same time three deaths were transferred to this age group from those who had previously been ' lapses'.

The net result of these changes is to increase the number of radiographed miners and ex-miners from 6,128 to 6,474 , thereby reducing the refusal rate from $5 \%$ to $3 \%$. It will also be noted from Table 1 that the percentage radiographed in the 20-64 age group, with which we are chiefly concerned, was $98.7 \%$.

\section{Method of Analysis}

The method we have used for the analysis of this material is that of the standardized mortality ratio (S.M.R.), i.e. 100 times the ratio of the number observed to the number of expected deaths in any group. The method of calculating the expected number of deaths from the death rates of England and Wales is not the same as that previously described by one of us (R.G.C.) (Carpenter et al., 1956). Had the previous method of estimating the expected number of deaths been used for the longer follow-up period, the S.M.R.s would for the most part have been appreciably nearer 100 than the ones shown. The method used in this paper is such as to give an S.M.R. as comparable as possible with the definition used in the Registrar General's tables of Occupational Mortality (1958), although our S.M.R.s are based on a follow-up study. The formulae required for calculating the S.M.R. and its standard error are given in the first section of the appendix, and a full discussion of the problem will be published elsewhere.

\section{Results}

General.-Table 2 summarizes the S.M.R.s for the two age groups (20 to 64 and 25 to 74 ) at the time of the first survey. The first point that will be noted in Table 2 is that the S.M.R. of non-miners is close to 100. This is reassuring as it implies that the effects of mining on mortality may be reasonably assessed by comparing the observed and expected numbers of deaths. Other points of interest in Table 2 are: (1) the close similarity between the S.M.R.s for ' all miners and ex-miners ' (149.0) and ' all radiographed miners and ex-miners' $(145.5)$ in spite of the high S.M.R. of those not radiographed. This suggests that the lapse rate for the original $x$-ray survey is no longer a source of error as far as the whole group is concerned. It could, of course, still be a source of error in some of the $x$-ray category sub-groups; (2) the high S.M.R. for those with P.M.F. (198.9); (3) the raised S.M.R. for those without P.M.F. (132-1); and (4) the similarity between the S.M.R. of those with category $0(134.0)$ and those with simple pneumoconiosis $(128 \cdot 8)$.

Comparison with Previous Data.-Table 3 has been constructed to be comparable with Table 5 of our previous paper (Carpenter et al., 1956). In that table categories 1,2 , and 3 simple pneumoconiosis were grouped with category A, so the same grouping has been used here. Table 3 suggests that when the few $x$-ray films were re-classified and the ages 
TABLE 2

STANDARDIZED MORTALITY RATIOS FOR MALES IN THE RHONDDA FACH 1950/51-1956

\begin{tabular}{|c|c|c|c|c|}
\hline Group 1950-51 & No. in Group & Observed Deaths & S.M.R. & S.E. ${ }^{-}$ \\
\hline $\begin{array}{l}\text { Ages } 20 \text { to } 64 \\
\text { All non-miners } \\
\text { All miners and ex-miners }\end{array}$ & $\begin{array}{l}2048 \\
5326\end{array}$ & $\begin{array}{r}62 \\
456\end{array}$ & $\begin{array}{l}106 \cdot 2 \\
149 \cdot 0\end{array}$ & $\begin{array}{l} \pm 13.48 \\
\pm 6.99\end{array}$ \\
\hline $\begin{array}{l}\text { Miners and ex-miners radiographed } \\
\text { Miners and ex-miners not radiographed }\end{array}$ & $\begin{array}{r}5258 \\
68\end{array}$ & $\begin{array}{r}438 \\
18\end{array}$ & $\begin{array}{l}145 \cdot 5 \\
361 \cdot 8\end{array}$ & $\begin{array}{l} \pm 6 \cdot 95 \\
\pm 94 \cdot 38\end{array}$ \\
\hline $\begin{array}{l}\text { Pneumoconiosis categories } 0,1,2 \text {, and } 3 \\
\text { Pneumoconiosis category } 0 \text {, and } 3 \\
\text { Pneumoconiosis categories } 1,2 \text {, and } \\
\text { Pneumoconiosis categories A, B, and C }\end{array}$ & $\begin{array}{r}4456 \\
2909 \\
1547 \\
802\end{array}$ & $\begin{array}{l}318 \\
207 \\
111 \\
120\end{array}$ & $\begin{array}{l}132 \cdot 1 \\
134 \cdot 0 \\
128 \cdot 8 \\
198 \cdot 9\end{array}$ & $\begin{array}{l} \pm 7 \cdot 41 \\
\pm 9 \cdot 28 \\
\pm 12 \cdot 26 \\
\pm 18 \cdot 18\end{array}$ \\
\hline $\begin{array}{l}\text { Ages } 25 \text { to } 74 \\
\text { All non-miners } \\
\text { All miners and ex-miners }\end{array}$ & $\begin{array}{l}1619 \\
5767\end{array}$ & $\begin{array}{r}88 \\
787\end{array}$ & $\begin{array}{l}114.9 \\
143.4\end{array}$ & $\begin{array}{l} \pm 12 \cdot 02 \\
\pm 5 \cdot 11\end{array}$ \\
\hline $\begin{array}{l}\text { Miners and ex-miners radiographed } \\
\text { Miners and ex-miners not radiographed }\end{array}$ & $\begin{array}{r}5642 \\
125\end{array}$ & $\begin{array}{r}725 \\
62\end{array}$ & $\begin{array}{l}136 \cdot 4 \\
357 \cdot 3\end{array}$ & $\begin{array}{l} \pm 5 \cdot 06 \\
\pm 48 \cdot 32\end{array}$ \\
\hline $\begin{array}{l}\text { Pneumoconiosis categories } 0,1,2 \text {, and } 3 \\
\text { Pneumoconiosis category } 0 \\
\text { Pneumoconiosis categories } 1,2 \text {, and } 3 \\
\text { Pneumoconiosis categories A, B, and C }\end{array}$ & $\begin{array}{r}4654 \\
2960 \\
1694 \\
988\end{array}$ & $\begin{array}{l}517 \\
331 \\
186 \\
208\end{array}$ & $\begin{array}{l}126 \cdot 1 \\
126 \cdot 9 \\
124 \cdot 9 \\
170 \cdot 8\end{array}$ & $\begin{array}{l} \pm 5 \cdot 55 \\
\pm \quad 6.96 \\
\pm 9.22 \\
\pm 11.76\end{array}$ \\
\hline
\end{tabular}

TABLE 3

COMPARISON WITH PREVIOUS DATA

\begin{tabular}{|c|c|c|c|c|c|c|c|c|c|c|c|c|c|c|c|c|c|c|}
\hline \multirow{3}{*}{$\begin{array}{c}\text { Age } \\
\text { Group }\end{array}$} & \multirow{3}{*}{$\begin{array}{c}\begin{array}{c}\text { Period } \\
\text { of } \\
\text { Follow-up }\end{array} \\
\end{array}$} & \multirow{3}{*}{ Data } & \multirow{3}{*}{$\begin{array}{c}\text { Method } \\
\text { of } \\
\text { Calculating } \\
\text { Expected } \\
\text { Deaths }\end{array}$} & \multicolumn{15}{|c|}{ Miners and Ex-miners } \\
\hline & & & & \multicolumn{5}{|c|}{ Category 0} & \multicolumn{5}{|c|}{ Categories 1, 2, 3 and $A$} & \multicolumn{5}{|c|}{ Categories $B$ and C } \\
\hline & & & & No. & $\begin{array}{c}\text { Obser- } \\
\text { ved } \\
\text { Deaths }\end{array}$ & $\begin{array}{c}\text { Expec- } \\
\text { ted } \\
\text { Deaths }\end{array}$ & S.M.R. & S.E. & No. & $\begin{array}{c}\text { Obser- } \\
\text { ved } \\
\text { Deaths }\end{array}$ & $\begin{array}{c}\text { Expec- } \\
\text { ted } \\
\text { Deaths }\end{array}$ & S.M.R. & S.E. & No. & $\begin{array}{c}\text { Obser- } \\
\text { ved } \\
\text { Deaths }\end{array}$ & $\begin{array}{c}\text { Expec- } \\
\text { ted } \\
\text { Deaths }\end{array}$ & S.M.R. & S.E. \\
\hline $20-64$ & \begin{tabular}{|l|}
$1950 / 51-53$ \\
$1950 / 51-53$ \\
$1950 / 51-53$ \\
$1950 / 51-56$
\end{tabular} & $\begin{array}{l}\text { Old } \\
\text { Revised } \\
\text { Revised } \\
\text { Revised }\end{array}$ & $\begin{array}{l}\text { Old } \\
\text { Old } \\
\text { New } \\
\text { New }\end{array}$ & $\begin{array}{l}2797 \\
2909 \\
2909 \\
2909\end{array}$ & $\begin{array}{r}72 \\
63 \\
63 \\
207\end{array}$ & $\begin{array}{r}60 \cdot 1 \\
62 \cdot 4 \\
62 \cdot 6 \\
154 \cdot 5\end{array}$ & $\begin{array}{l}119 \cdot 8 \\
100 \cdot 9 \\
100 \cdot 6 \\
134 \cdot 0\end{array}$ & $\begin{array}{l} \pm 14 \cdot 12 \\
\pm 12 \cdot 71 \\
\pm 12 \cdot 60 \\
\pm 9 \cdot 28\end{array}$ & $\begin{array}{l}1772 \\
1860 \\
1860 \\
1860\end{array}$ & $\begin{array}{r}52 \\
60 \\
60 \\
135\end{array}$ & $\begin{array}{r}40 \cdot 7 \\
43 \cdot 6 \\
43 \cdot 1 \\
107 \cdot 1\end{array}$ & $\begin{array}{l}127 \cdot 8 \\
137 \cdot 7 \\
139 \cdot 2 \\
126 \cdot 1\end{array}$ & $\begin{array}{l} \pm 17 \cdot 72 \\
\pm 17 \cdot 78 \\
\pm 17 \cdot 80 \\
\pm 10.85\end{array}$ & $\begin{array}{l}460 \\
489 \\
489 \\
489\end{array}$ & $\begin{array}{l}22 \\
28 \\
28 \\
96\end{array}$ & $\begin{array}{l}15 \cdot 8 \\
16.7 \\
16.4 \\
39 \cdot 4\end{array}$ & $\begin{array}{l}139 \cdot 2 \\
167 \cdot 6 \\
170 \cdot 3 \\
243 \cdot 6\end{array}$ & $\begin{array}{l} \pm 29.69 \\
\pm 31.67 \\
\pm 32.21 \\
\pm 24.89\end{array}$ \\
\hline $25-74$ & $\begin{array}{l}1950 / 51-53 \\
1950 / 51-53 \\
1950 / 51-53 \\
1950 / 51-56\end{array}$ & $\begin{array}{l}\text { Old } \\
\text { Revised } \\
\text { Revised } \\
\text { Revised }\end{array}$ & $\begin{array}{l}\text { Old } \\
\text { Old } \\
\text { New } \\
\text { New }\end{array}$ & $\begin{array}{l}2826 \\
2960 \\
2960 \\
2960\end{array}$ & $\begin{array}{l}115 \\
111 \\
111 \\
331\end{array}$ & $\begin{array}{l}104 \cdot 4 \\
110 \cdot 6 \\
110 \cdot 4 \\
260.9\end{array}$ & $\begin{array}{l}110 \cdot 2 \\
100 \cdot 3 \\
100 \cdot 5 \\
126 \cdot 8\end{array}$ & $\begin{array}{rr} \pm & 10 \cdot 27 \\
\pm & 9 \cdot 52 \\
\pm & 9 \cdot 53 \\
\pm & 6.96\end{array}$ & $\begin{array}{l}1950 \\
2065 \\
2065 \\
2065\end{array}$ & $\begin{array}{r}82 \\
97 \\
97 \\
228\end{array}$ & $\begin{array}{r}73 \cdot 9 \\
81 \cdot 4 \\
80 \cdot 5 \\
191 \cdot 3\end{array}$ & $\begin{array}{l}111.0 \\
119.2 \\
120.4 \\
119.2\end{array}$ & $\begin{array}{r} \pm 12 \cdot 25 \\
\pm 12 \cdot 10 \\
\pm 12 \cdot 18 \\
\pm 7 \cdot 88\end{array}$ & $\begin{array}{l}579 \\
617 \\
617 \\
617\end{array}$ & $\begin{array}{r}47 \\
53 \\
53 \\
166\end{array}$ & $\begin{array}{l}33.9 \\
36 \cdot 2 \\
35.4 \\
79 \cdot 4\end{array}$ & $\begin{array}{l}138.6 \\
146.6 \\
149.9 \\
209.2\end{array}$ & $\begin{array}{l} \pm 20.22 \\
\pm 20.14 \\
\pm 20.71 \\
\pm 16.02\end{array}$ \\
\hline
\end{tabular}

Note: The expected deaths are shown corrected to the first decimal place. The S.M.R.s shown are calculated before correcting.

corrected, the grade of pneumoconiosis was increased, especially among the younger men who died. Thus, the population of men with category 0 aged 20 to 64 was increased by $4 \%$ due to the reduction of the lapse rates, but the number of deaths in this age group in the $1950 / 51$ to 1953 period was reduced by $12.5 \%$. Among those with categories $\mathrm{B}$ and $\mathrm{C}$ in this age group, the changes have increased the population by $6.3 \%$ and the number of deaths by $27 \%$. This change is of the type to be expected if lapse rates are reduced, i.e. the proportion of deaths would be expected to rise because the death rates are in general higher among the defaulters than in the rest of the population.

The results of the two methods of computing S.M.R.s are compared in Table 3 on the revised $1950 / 51$ to 1953 data. For men with pneumoconiosis, whose mortality experience generally exceeds expectation, the new method, as might be predicted from theoretical considerations, gives an S.M.R. which is larger than that obtained by the old method. When the mortality experience of a group does not show a consistent deviation from expectation, the new method of calculating S.M.R.s will not necessarily be further from 100 than the old, and in fact in the case of men in category 0 the reverse is true.

The S.M.R.s for the period of the six-year followup are also shown in Table 3. Neither the revision of the data nor revising the method of calculating S.M.R.s nor extending the duration of the follow-up has greatly affected the S.M.R.s of men in categories 1, 2, 3, and A. However, the prolonged follow-up has enabled us to say that the deviation of their S.M.R. from 100 is unlikely to be fortuitous.

In the category 0 group there seems to be a significant increase in the S.M.R. associated with the increased length of the follow-up. The reason for this is not clear. In the category $\mathrm{B}$ and $\mathrm{C}$ group there is a similar but much more striking effect which requires a more detailed discussion. A recent paper (Coch- 
TABLE 4

COMPARISON OF AVERAGE AREA OF P.M.F. IN EACH AGE GROUP, 1950-51 AND 1958

\begin{tabular}{|c|c|c|c|c|c|c|}
\hline \multirow[b]{2}{*}{$\begin{array}{c}\text { Age } \\
\text { Group }\end{array}$} & \multicolumn{3}{|c|}{$1950-51$} & \multicolumn{3}{|c|}{1958} \\
\hline & No. in Group & $\begin{array}{c}\text { Average Area } \\
\text { of P.M.F. } \\
\left(\mathrm{cm}^{\mathbf{2}} .\right)\end{array}$ & S.E. & No. in Group & $\begin{array}{c}\text { Average Area } \\
\text { of P.M.F. } \\
\left(\mathrm{cm}^{2} .\right)\end{array}$ & S.E. \\
\hline $\begin{array}{l}25-34 \\
35-44 \\
45-54 \\
55-64 \\
65-74 \\
75-84\end{array}$ & $\begin{array}{r}60 \\
177 \\
201 \\
231 \\
165 \\
38\end{array}$ & $\begin{array}{l}23 \cdot 29 \\
34 \cdot 77 \\
33 \cdot 41 \\
33 \cdot 24 \\
33 \cdot 36 \\
29 \cdot 73\end{array}$ & $\begin{array}{l} \pm 4.19 \\
\pm 2.67 \\
\pm 2.51 \\
\pm 2.13 \\
\pm 2.34 \\
\pm 3.21\end{array}$ & $\begin{array}{r}8 \\
79 \\
160 \\
157 \\
128 \\
44\end{array}$ & $\begin{array}{l}25 \cdot 31 \\
47 \cdot 55 \\
56 \cdot 59 \\
43 \cdot 55 \\
38 \cdot 38 \\
30 \cdot 81\end{array}$ & $\begin{array}{l} \pm 6.34 \\
\pm 4.04 \\
\pm 3.40 \\
\pm 2.93 \\
\pm 2.74 \\
\pm 4.18\end{array}$ \\
\hline
\end{tabular}

rane, Moore, and Thomas, 1961b) has shown that the case fatality of P.M.F. is related to the initial area of the P.M.F. shadow, so the S.M.R. of a group will depend on the distribution of the areas of the shadows at the time when the S.M.R. is measured. If we then consider a population of miners with P.M.F., to which no new cases are added, over a period of time, the distribution of the areas will change as time passes, and the new distribution will be the resultant of the progression rate and the case fatality rate. If the progression rate were relatively high and the case fatality relatively low, the mean size would increase, as would the S.M.R. To investigate this possibility we carried out a subsidiary investigation on a population of 872 men with P.M.F., of which the survivors had been reradiographed eight years later. The areas of the P.M.F. shadows were drawn on tracing paper and measured for all the first films, and for the second films of those who survived. The results are summarized in the Figure and in Table 4, which show the distribution of these areas by age in 1950-51 and those of the survivors in 1958. This clearly demonstrates the expected increase in mean size and explains part of the changes in the S.M.R.s of those with categories $B$ and $C$ seen in Table 3.

The Raised S.M.R. of Miners and Ex-miners without P.M.F.-Table 2 shows that miners with categories $0,1,2$, and 3 have an S.M.R. significantly higher than expected, while non-miners do not. There are various possible reasons for this.

(a) The Effect of Colliery Accidents.-The Registrar General's tables of Occupational Mortality (1958) show that in miners aged 20 to $64,9.5 \%$ of all deaths are due to accidents other than home or motor accidents. Most, but not all, of these fatal accidents will be colliery accidents. The corresponding percentage of industrial accidents for all males is $2 \cdot 9$, and the S.M.R. of miners for this cause of death is 383 .

The groups of men we have followed up were initially aged 20 to 64 , but by the end of the survey the ages were 26 to 70 . They also include men who

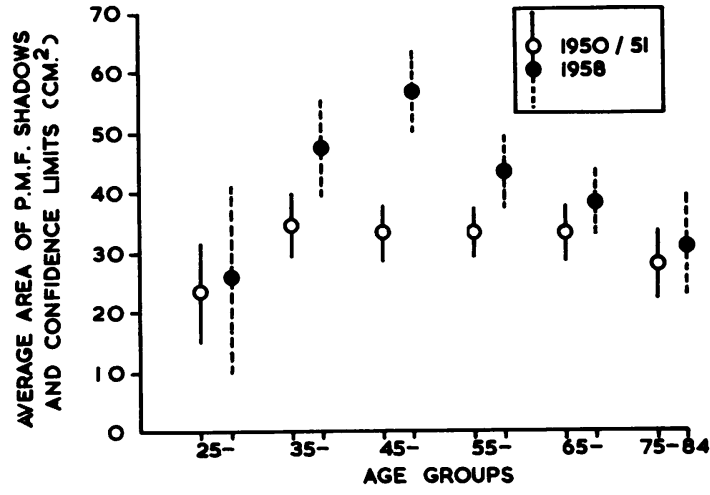

FIGURE.-Comparison of average areas of P.M.F. shadows and their $95 \%$ confidence limits in each age group of Rhondda Fach miners and ex-miners in $1950-51$ and 1958 .

were ex-miners as well as miners. Nevertheless, in category $0,5 \%$ of the deaths were due to colliery accidents, and in categories 1,2 , and $3,6 \%$ of the deaths were due to this cause. On the other hand, among the men working as miners in 1950-51 and initially aged 20 to 64,18 colliery fatal accidents occurred during the follow-up period, $10 \%$ of all deaths in this group. The figures are not quite comparable with the Registrar General's figures but indicate that the colliery fatal accident rate observed in the Rhondda Fach has been slightly, but not significantly, higher than the average for the industry.

Table 5 compares the S.M.R.s of miners in category 0 and in categories 1,2 , and 3 before and after colliery accidents have been excluded. The method used for calculating the S.M.R.s when colliery accidents are excluded is described in the second section of the appendix (p. 45). As is pointed out in the appendix, this method slightly exaggerates the effect of excluding colliery accidents. Nonetheless, the results shown in Table 5 demonstrate that colliery accidents only account for a small proportion of the excess of deaths observed in this group of miners, and that even if this cause of death is excluded there is still a considerable excess of deaths. 
TABLE 5

THE EFFECT ON STANDARDIZED MORTALITY RATIOS OF EXCLUDING COLLIERY ACCIDENTS

\begin{tabular}{|c|c|c|c|c|c|c|c|c|c|}
\hline \multirow{3}{*}{$\begin{array}{c}\text { Age } \\
\text { Range } \\
1950-51\end{array}$} & \multirow{3}{*}{ Group } & \multicolumn{8}{|c|}{ Miners and Ex-miners } \\
\hline & & \multicolumn{4}{|c|}{ Category 0} & \multicolumn{4}{|c|}{ Categories 1, 2, and 3} \\
\hline & & $\begin{array}{l}\text { No. in } \\
\text { G roup }\end{array}$ & $\begin{array}{l}\text { Observed } \\
\text { Deaths }\end{array}$ & S.M.R. & S.E. & $\begin{array}{l}\text { No. in } \\
\text { Group }\end{array}$ & $\begin{array}{l}\text { Observed } \\
\text { Deaths }\end{array}$ & S.M.R. & S.E. \\
\hline $20-64$ & $\begin{array}{l}\text { Including colliery accidents } \\
\text { Excluding colliery accidents }\end{array}$ & $\begin{array}{l}2,909 \\
2,909\end{array}$ & $\begin{array}{l}207 \\
196\end{array}$ & $\begin{array}{l}134 \cdot 0 \\
126 \cdot 8\end{array}$ & $\begin{array}{l} \pm 9 \cdot 28 \\
\pm 9 \cdot 00\end{array}$ & $\begin{array}{l}1,547 \\
1,547\end{array}$ & $\begin{array}{l}111 \\
104\end{array}$ & $\begin{array}{l}128 \cdot 8 \\
120 \cdot 5\end{array}$ & $\begin{array}{l} \pm 12 \cdot 26 \\
\pm 11 \cdot 79\end{array}$ \\
\hline $25-74$ & $\begin{array}{l}\text { Including colliery accidents } \\
\text { Excluding colliery accidents }\end{array}$ & $\begin{array}{l}2,960 \\
2,960\end{array}$ & 331 & $\begin{array}{l}126 \cdot 9 \\
123 \cdot 7\end{array}$ & $\begin{array}{l} \pm 6.96 \\
\pm 6.85\end{array}$ & $\begin{array}{l}1,694 \\
1,694\end{array}$ & $\begin{array}{l}186 \\
179\end{array}$ & $\begin{array}{l}124 \cdot 9 \\
120 \cdot 1\end{array}$ & $\begin{array}{l} \pm 9 \cdot 22 \\
\pm 8.99\end{array}$ \\
\hline
\end{tabular}

TABLE 6

STANDARDIZED MORTALITY RATIOS BY $X$-RAY CATEGORY OF PNEUMOCONIOSIS EXCLUDING COLLIERY ACCIDENTS

\begin{tabular}{|c|c|c|c|c|c|c|}
\hline Group & $\begin{array}{l}\text { No. in } \\
\text { Group }\end{array}$ & $\begin{array}{l}\text { Observed } \\
\text { Deaths }\end{array}$ & $\begin{array}{l}\text { Colliery } \\
\text { Accident } \\
\text { Deaths }\end{array}$ & $\begin{array}{l}\text { Other } \\
\text { Deaths }\end{array}$ & S.M.R. & S.E. \\
\hline $\begin{array}{l}\text { Ages } 20 \text { to } 64 \\
\text { Non-miners }\end{array}$ & 2,048 & 62 & - & 62 & $106 \cdot 2$ & \pm 13.48 \\
\hline $\begin{array}{l}\text { Miners and ex-miners } \\
\text { Pneumoconiosis category } 0 \\
\text { Pneumoconiosis category } 1 \\
\text { Pneumoconiosis categories } 2 \text { and } 3 \\
\text { Pneumoconiosis categories } 1,2 \text {, and } 3 \\
\text { Pneumoconiosis categories A, B, and C }\end{array}$ & $\begin{array}{r}2,909 \\
681 \\
866 \\
1,547 \\
802\end{array}$ & $\begin{array}{r}207 \\
61 \\
50 \\
111 \\
120\end{array}$ & $\begin{array}{r}11 \\
3 \\
4 \\
7 \\
-\end{array}$ & $\begin{array}{r}196 \\
58 \\
46 \\
104 \\
120\end{array}$ & $\begin{array}{l}126 \cdot 8 \\
140 \cdot 2 \\
102 \cdot 3 \\
120 \cdot 5 \\
198 \cdot 9\end{array}$ & $\begin{array}{l} \pm 9 \cdot 00 \\
\pm 18 \cdot 43 \\
\pm 15 \cdot 03 \\
\pm 11 \cdot 79 \\
\pm 18 \cdot 18\end{array}$ \\
\hline $\begin{array}{l}\text { Ages } 25 \text { to } 74 \\
\text { Non-miners }\end{array}$ & 1,619 & 88 & - & 88 & 114.9 & \pm 12.02 \\
\hline $\begin{array}{l}\text { Miners and ex-miners } \\
\text { Pneumoconiosis category } 0 \\
\text { Pneumoconiosis category } 1 \\
\text { Pneumoconiosis categories } 2 \text { and } 3 \\
\text { Pneumoconiosis categories } 1,2 \text {, and } 3 \\
\text { Pneumoconiosis categories A, B, and C }\end{array}$ & $\begin{array}{r}2,960 \\
755 \\
939 \\
1,694 \\
988\end{array}$ & $\begin{array}{r}331 \\
94 \\
92 \\
186 \\
208\end{array}$ & $\begin{array}{r}8 \\
3 \\
4 \\
7 \\
-\end{array}$ & $\begin{array}{r}323 \\
91 \\
88 \\
179 \\
208\end{array}$ & $\begin{array}{l}123.7 \\
120.0 \\
120.1 \\
120.1 \\
170.8\end{array}$ & $\begin{array}{l} \pm 6.85 \\
\pm 12.61 \\
\pm 12.68 \\
\pm 8.99 \\
\pm 11.76\end{array}$ \\
\hline
\end{tabular}

The question of the relation between the risk of dying from colliery accidents and that of dying from P.M.F. is one that is sometimes raised, and the material here enables us to attempt an answer by relating the number of colliery accidents to the excess deaths due to P.M.F. For the age group 20 to 64 , over this particular period and in this particular community the ratio would be 18 colliery accidents to $59 \cdot 6$ excess deaths in the P.M.F. group or $1: 3 \cdot 3$. It should, however, be stressed that the ratio is very sensitive to age, because few colliery accidents occur in men over 65 years of age, and to region, owing to the variation in the prevalence of P.M.F.; and it would be very different if only working miners were concerned.

(b) The Effect of Category of Simple Pneumoconiosis.-If simple pneumoconiosis were an important cause of the raised S.M.R., one would in general expect that there would be an increasing S.M.R. with increasing category of simple pneumoconiosis. The break down by $x$-ray category of simple pneumoconiosis is shown in Table 6 . In the 20 to 64 age group the effect of category is irregular, while in the
25 to 74 age group there is clearly no effect at all. There is thus no evidence that simple pneumoconiosis per se has any effect on life expectancy.

(c) With what Causes of Death is this Raised S.M.R. Associated?-This has been investigated by calculating 'expected' deaths from respiratory and non-respiratory diseases (Table 7). The methods used are described in the third section of the appendix. Table 7 shows that for non-miners aged 20 to 64 there was an excess of respiratory deaths compared with the number expected, but the excess only amounts to three deaths in six years and is not statistically significant. Table 7 also shows that colliery accidents and respiratory deaths together account for much of the excess mortality observed in men with simple pneumoconiosis. The respiratory S.M.R.s for P.M.F. (A, B, and C) are, as expected, very high but the low non-respiratory S.M.R.s in this group serve as a reminder of the possibility that doctors in an area with a known high prevalence of pneumoconiosis may have a bias in favour of giving a respiratory rather than a non-respiratory cause of death in a doubtful case. 
TABLE 7

STANDARDIZED MORTALITY RATIOS FOR RESPIRATORY AND NON-RESPIRATORY DISEASES OF NON-MINERS AND MINERS AND EX-MINERS BY CATEGORY OF PNEUMOCONIOSIS

\begin{tabular}{|c|c|c|c|c|c|c|c|c|c|c|c|}
\hline \multirow{2}{*}{ Age Group } & \multirow{2}{*}{ Group } & \multicolumn{5}{|c|}{ Respiratory Deaths } & \multicolumn{5}{|c|}{$\begin{array}{c}\text { Non-respiratory Deaths } \\
\text { (excluding colliery accidents) }\end{array}$} \\
\hline & & No. & $\begin{array}{c}\text { Observed } \\
\text { Deaths }\end{array}$ & $\begin{array}{c}\text { Expected } \\
\text { Deaths }\end{array}$ & S.M.R. & S.E. & No. & $\begin{array}{c}\text { Observed } \\
\text { Deaths }\end{array}$ & $\begin{array}{c}\text { Expected } \\
\text { Deaths }\end{array}$ & S.M.R. & S.E. \\
\hline $20-64$ & $\begin{array}{l}\text { Non-miners } \\
\text { Miners and ex-miners } \\
\text { Category 0 } \\
\text { Categories 1, 2, 3 } \\
\text { Categories A, B, C }\end{array}$ & $\begin{array}{r}2,048 \\
2,909 \\
1,547 \\
802\end{array}$ & $\begin{array}{l}51 \\
25 \\
74\end{array}$ & $\begin{array}{l}25.9 \\
15 \cdot 0 \\
10 \cdot 7\end{array}$ & $\begin{array}{l}131 \cdot 5 \\
197 \cdot 3 \\
166 \cdot 8 \\
699 \cdot 2\end{array}$ & $\begin{array}{l} \pm 36 \cdot 48 \\
\pm 27 \cdot 63 \\
\pm 33 \cdot 36 \\
\pm 81 \cdot 28\end{array}$ & $\begin{array}{r}2,048 \\
\\
2,909 \\
1,547 \\
802\end{array}$ & $\begin{array}{r}49 \\
\\
145 \\
79 \\
46\end{array}$ & $\begin{array}{r}48 \cdot 5 \\
\\
128 \cdot 6 \\
71 \cdot 2 \\
49 \cdot 7\end{array}$ & $\begin{array}{r}101 \cdot 0 \\
113 \cdot 3 \\
111 \cdot 0 \\
92 \cdot 5\end{array}$ & $\begin{array}{r} \pm 14 \cdot 43 \\
\pm \quad 9 \cdot 36 \\
\pm 12 \cdot 48 \\
\pm 13 \cdot 65\end{array}$ \\
\hline $25-74$ & $\begin{array}{l}\text { Non-miners } \\
\text { Miners and ex-miners } \\
\text { Category } 0 \\
\text { Categories } 1,2,3 \\
\text { Categories A, B, C }\end{array}$ & $\begin{array}{r}2,960 \\
1,694 \\
988\end{array}$ & $\begin{array}{r}86 \\
44 \\
122\end{array}$ & $\begin{array}{l}41 \cdot 1 \\
25 \cdot 7 \\
19 \cdot 9\end{array}$ & $\begin{array}{l}117 \cdot 8 \\
209 \cdot 2 \\
171 \cdot 4 \\
611 \cdot 5\end{array}$ & $\begin{array}{l} \pm 30 \cdot 41 \\
\pm 22 \cdot 56 \\
\pm 25 \cdot 84 \\
\pm 55 \cdot 36\end{array}$ & $\begin{array}{r}1,619 \\
2,960 \\
1,694 \\
988\end{array}$ & $\begin{array}{r}237 \\
135 \\
86\end{array}$ & \begin{tabular}{r|}
$63 \cdot 8$ \\
\\
$219 \cdot 6$ \\
$123 \cdot 3$ \\
$101 \cdot 8$
\end{tabular} & $\begin{array}{r}114 \cdot 4 \\
107 \cdot 9 \\
109 \cdot 5 \\
84 \cdot 5\end{array}$ & $\begin{array}{l} \pm 13.39 \\
\pm \quad 7.01 \\
\pm \quad 9.42 \\
\pm \quad 9.11\end{array}$ \\
\hline
\end{tabular}

TABLE 8

STANDARDIZED MORTALITY RATIOS OF MINERS AND EX-MINERS

\begin{tabular}{|c|c|c|c|c|c|c|c|c|c|c|c|c|c|c|c|}
\hline \multirow{2}{*}{$\begin{array}{c}\text { Age } \\
\text { Range }\end{array}$} & \multicolumn{5}{|c|}{ Miners (1950-51) } & \multicolumn{5}{|c|}{$\begin{array}{c}\text { Miners (1950-51) } \\
\text { (excluding colliery accidents) }\end{array}$} & \multicolumn{5}{|c|}{ Ex-miners (1950-51) } \\
\hline & No. & $\begin{array}{c}\text { Observed } \\
\text { Deaths }\end{array}$ & $\begin{array}{c}\text { Expected } \\
\text { Deaths }\end{array}$ & S.M.R. & S.E. & No. & $\begin{array}{c}\text { Observed } \\
\text { Deaths }\end{array}$ & $\begin{array}{c}\text { Expected } \\
\text { Deaths }\end{array}$ & S.M.R. & S.E. & No. & $\begin{array}{l}\text { Observed } \\
\text { Deaths }\end{array}$ & $\begin{array}{l}\text { Expected } \\
\text { Deaths }\end{array}$ & S.M.R. & S.E. \\
\hline $\begin{array}{l}20-64 \\
25-74\end{array}$ & $\begin{array}{l}2789 \\
2613\end{array}$ & $\begin{array}{l}174 \\
192\end{array}$ & $\begin{array}{l}134 \cdot 3 \\
162 \cdot 7\end{array}$ & $\begin{array}{l}129.6 \\
118.0\end{array}$ & $\begin{array}{l} \pm 9 \cdot 78 \\
\pm 8 \cdot 49\end{array}$ & $\begin{array}{l}2789 \\
2613\end{array}$ & $\begin{array}{l}156 \\
177\end{array}$ & $\begin{array}{l}134 \cdot 3 \\
162 \cdot 7\end{array}$ & $\begin{array}{l}116.2 \\
108 \cdot 8\end{array}$ & $\begin{array}{l} \pm 9 \cdot 25 \\
\pm 8 \cdot 16\end{array}$ & $\begin{array}{l}2537 \\
3154\end{array}$ & $\begin{array}{l}282 \\
595\end{array}$ & $\begin{array}{l}171 \cdot 7 \\
386 \cdot 3\end{array}$ & $\begin{array}{l}164 \cdot 3 \\
154 \cdot 0\end{array}$ & $\begin{array}{l} \pm 9.85 \\
\pm 6.35\end{array}$ \\
\hline
\end{tabular}

The S.M.R.s of Miners and Ex-miners.-The Registrar General is the accepted authority on the mortality of occupied and retired miners, and the size of his populations makes our numbers seem puny. However, our population has an advantage in that it contains those who left the mining industry and took other jobs. Such men should be automatically excluded from the Registrar General's populations since the death certificate only refers to the last occupation of the deceased. In South Wales particularly, many miners have left the industry because of pneumoconiosis and taken other jobs, so it is possible that our population may be, for this particular area, more representative than the Registrar General's ' occupied and retired miners'.

Table 8 gives the S.M.R.s for our 'miners' and ' ex-miners' as previously defined. Our ' miners' are not exactly the same as the Registrar General's ' occupied and retired miners' but must approximate closely to them. The most recent of the Registrar General's S.M.R.s for coal-miners, as corrected by Heasman and his colleagues (Heasman, Liddell, and Reid, 1958), was 100.0. The same material has been analysed (but not published) by Professor D. D. Reid for the different regions of the National Coal Board. The figure for the Southwestern Region was 117 (Reid, personal communication, 1961). Our figure for miners is higher and the figure for ex-miners higher still. This certainly sug- gests, without of course proving, that the S.M.R.s for 'occupied and retired' coal-miners may underestimate the risks associated with the industry in some areas.

\section{Discussion}

As regards the miners and ex-miners without P.M.F., all the evidence suggests that their S.M.R. is higher than that for non-miners, but that the excess, although probably respiratory in origin, is not related to the category of simple pneumoconiosis. This agrees surprisingly well with the results of pulmonary disability surveys in the Rhondda Fach. The average ventilatory function of miners and ex-miners aged 55 to 64 without P.M.F. is significantly lower than that of non-miners of the same age living in the same area. There was also no relation between the category of simple pneumoconiosis and the average ventilatory function. In an area in Derbyshire, the average ventilatory function of miners and ex-miners without P.M.F. is very similar to that of the nonminers (Cochrane, Higgins, and Thomas, 1961) so it seems possible that S.M.R.s might be similar too. At any rate it is clearly inadvisable to assume that the S.M.R.s found in the Rhondda Fach are generally applicable.

Our results as regards the lack of relation between the category of simple pneumoconiosis on the one 
hand and ventilatory function and mortality on the other are not in agreement with those of the National Coal Board which finds a clear-cut relation between category and ventilatory function (Rogan, Ashford, Chapman, Duffield, Fay, and Rae, 1961). Their results are admittedly closer to what one might have expected, and the discrepancy may well be explained by a greater degree of occupational self-selection amongst miners in the Rhondda Fach.

The S.M.R. of those with P.M.F. raises similar and also additional problems. If the raised S.M.R. of those without P.M.F. is due to non-mining causes, the S.M.R. of those with P.M.F. should be proportionately reduced, i.e. from 198.9 to 156 , but the present evidence is too uncertain. The alteration of the S.M.R. with time makes an estimate of the 'true' S.M.R. even more difficult. It seems probable that the lethality of P.M.F. is better characterized by case fatality ratios standardized by age and the original area of shadow (Cochrane et al., 1961b).
Such a long-term study could not be completed without the co-operation of a very large number of people. To mention them all would be invidious. We can only express our gratitude to everyone concerned.

\section{REFERENCES}

Carpenter, R. G., Cochrane, A. L., Clarke, W. G., Jonathan, G., and Moore, F. (1956). Brit. J. industr. Med., 13, 102.

Cochrane, A. L., Carpenter, R. G., Clarke, W. G., Jonathan, G., and Moore, F. (1956). Ibid., 13, 177.

Higgins, I. T. T., and Thomas, J. (1961). Brit. J. prev. soc. Med., 15,1 .

- Moore, F., and Thomas, J. (1961a). Tubercle (Lond.), 42, 72. $\longrightarrow,-\longrightarrow$, (1961b). Ibid., 42, 64.

Heasman, M. A., Liddell, F. D. K., and Reid, D. D. (1958). Brit. J. industr. Med., 15, 141.

International Labour Organisation (1953). Third International Conference of Experts on Pneumoconiosis, Sydney 1950. Record of ference of Experts on Pneum
Proceedings, Vol. 1, p. 104.

Registrar General's Decennial Supplement, England and Wales, 1951. Occupational Mortality Part II, Vol. 1, p. 95 (H.M.S.O. 1958).

Rogan, J. M., Ashford, J. R., Chapman, P. J., Duffield, D. P., Fay, J. W. J., and Rae, S. (1961). Brit. med. J., i, 1337 .

\title{
APPENDIX
}

\section{Method of Calculating the S.M.R.s and their Standard Errors}

\author{
by \\ R. G. Carpenter
}

The first step in calculating the S.M.R. for a group or cohort of men who have been followed up for a number of years is to calculate the expected death rates for each 10year cohort sub-group for each year of the period covered by the follow-up.

The population that we have followed up in the Rhondda Fach was divided into five- and 10-year cohort groups by sorting on age last birthday on January 1, 1951. The Registrar General tabulates death rates for groups based on age last birthday at the mid-year. Thus in 1951 our cohort groups were on the average six months older than the corresponding age groups for which death rates are tabulated. In 1952 the cohorts were one and a half years older, and in 1953 two and a half years older, than the tabulated age groups, and so on. The expected death rates for age groups corresponding to those of the cohorts were derived as described in the appendix of our previous paper (Carpenter et al., 1956). That is, the death rates for these age groups were derived by linear interpolation on the logarithms of the tabulated death rates. The follow-up only covered the first 11 months of 1956. The analysis for this year is the same as for other years except that the tabulated death rates for England and Wales are replaced by 1,000 times the ratio of deaths in the country during the first 11 months of the year to the mid-period (taken as the mid-year) population.
Both J. Thomas and I, using different methods, have independently investigated the accuracy of deriving the expected death rates of intermediate age groups by this method of interpolation, and we both concluded that it is satisfactory.

In the appendix of the previous paper, I gave a formula for deriving the expected number of deaths in a cohort from the initial population and the expected death rates. But the formula does not take account of the mortality experience of the group concerned. To derive an S.M.R. as comparable as possible to the Registrar General's definition, as used in his tables of Occupational Mortality (1958), it is necessary to take account of the mortality experience of the group. The longer the period of followup the more important this becomes. The following formulae make the necessary adjustments.

Let the group of people followed up be divided into $I$ five- or 10-year cohorts, and at the start of the survey let there be $p_{i}$ subjects in each cohort ( $i$ goes from 1 to $I$ ). The follow-up lasts for $J$ years, and it is assumed, as in the present study, that all the subjects are traced. Of the $i$ th cohort $d_{i j}$ die in the $j$ th year of the follow-up. Let

$$
D_{i} \underset{j=1}{J} d_{i j}
$$


Also denote the expected death rate in the $i$ th cohort the $j$ th year of the follow-up by $r_{i}$, where $r$ is calculated from the national death rates as already described.

Define

and for $j=1$ to $J-1$

$$
a_{i J}=r_{i J} / 2
$$

$$
a_{i j}=r_{i j} / 2+\sum_{t=j+1}^{J} r_{i t} \ldots \ldots \ldots \ldots \ldots
$$

Also let

$$
\begin{aligned}
A_{i} & =p_{i} \underset{j}{\sum r_{i j}} \\
B_{i} & =\sum_{j} a^{2}{ }_{i j} d_{i j} \\
C_{i} & =\sum_{j} a_{i j} d_{i j}
\end{aligned}
$$

Then if we denote the fact that the S.M.R. is derived from a cohort study by a subscript $c$, the definition, which is comparable to that of the Registrar General's, is:-

$$
\text { S.M.R.c }=\frac{100 \sum D_{i}}{\sum_{i}\left(A_{i}-C_{i}\right)}=100 \mathrm{~S} \ldots \ldots \ldots
$$

It may also be shown that the variance of this expression is given by:-

$\operatorname{Var}($ S.M.R.c) $=$

$$
\sum_{i}\left\{D_{i}+2 S C_{i}+B_{i} S^{2}-\frac{1}{p_{i}}\left(D_{i}+S C_{i}\right)^{2}\right\} 10^{4}
$$

$$
\left\{\begin{array}{l}
\left.\Sigma_{i}\left(A_{i}-C_{i}\right)\right\}^{2} \\
\text {. }
\end{array}\right.
$$

The derivation of these formulae and the assumptions involved will be published elsewhere.

The S.M.R.s, Colliery Accidents Excluded.-The method used for calculating the S.M.R.s, colliery accidents excluded, was to assume that the men concerned would otherwise have survived. The effect of assuming that these men survived, instead of regarding them as lost from the population from the time they died, has a negligible effect on the calculated expected numbers of deaths and on the standard error of the S.M.R.

The expected death rates have also not been revised to exclude 'other accidents' since they form so small a fraction of the total expected deaths, and also because 'other accidents' are not all industrial accidents. In consequence, the S.M.R.s, colliery accidents excluded, may be under-estimated by as much as $2 \frac{1}{2} \%$.

The S.M.R.s for Respiratory and Non-respiratory Deaths.-The S.M.R.s for respiratory and non-respiratory deaths were calculated by J. Thomas as follows. For the standard age groups the proportion of deaths in England and Wales due to respiratory causes, including tuberculosis, may be derived for any year from the appropriate volume of the Registrar General's Statistical Review. The expected proportions of respiratory deaths in the non-standard five- and 10-year age groups, corresponding to those of the cohorts, were obtained from these figures by linear interpolation.

Let $b_{i j}$ be the expected proportion of deaths due to respiratory causes in the $j$ th year of the survey and in the age group corresponding to that of the $i$ th cohort in that year. Then the expected respiratory death rate is:-

$$
r_{i j}^{\prime}=r_{i j} b_{i j}
$$

and the expected non-respiratory death rate is:-

$$
r_{i j}-r_{i j}^{\prime}
$$

Let $a^{\prime}{ }_{i j}, A^{\prime}$, and $C^{\prime}{ }_{i}$ correspond to $a_{i j}, A_{i}$, and $C_{i}$, as defined by equations (1), (2), and (4), when $r^{\prime}{ }_{i j}$ and $a^{\prime}{ }_{i j}$ replace $r_{i j}$ and $a_{i j}$ in the right-hand side of these equations. Then the expected number of respiratory deaths in the cohort is given by:-

$$
\sum_{i}\left(A^{\prime}{ }_{i}-C^{\prime}{ }_{i}\right)
$$

and the S.M.R. for respiratory deaths is given by 100 times the observed respiratory deaths divided by the expected respiratory deaths. The S.M.R. for nonrespiratory deaths is:-

100 (total observed non-respiratory deaths)

(total expected deaths) - (total expected respiratory deaths)

Determining the S.M.R. of deaths due to a particular cause is analogous to determining the S.M.R. of a cohort which is being depleted by losses other than death. An approximate formula for the standard error of such an S.M.R., comparable to that given by equation (6), has been derived, but it is complicated, and the computations required to evaluate it are substantial. For the present purpose it is sufficient to over-estimate the standard error (s.e.) by using the simple first approximation given by:-

$$
\text { s.e. }= \pm \frac{100}{\sqrt{\text { (observed respiratory deaths) }}}
$$

A similar expression was used to estimate the standard error of the S.M.R. for non-respiratory deaths. 